\title{
Characterization of rat epithelial epididymal cells purified on a discontinuous Percoll gradient
}

\author{
C. Finaz* $\ddagger$, F. Boué*, G. Meduri $\dagger$ and A. Lefèvre* $\ddagger$
}

*I.N.S.E.R.M. Unité 293, I rue Maurice Arnoux, 92120 Montrouge, France; and $\dagger$ Laboratoire d'Anatomie Pathologique, Hôpital du Kremlin Bicêtre, 94270 Kremlin Bicêtre, France

\begin{abstract}
Summary. A method for the purification of epithelial cells from the three anatomical regions of the rat epididymis (corpus, caput and cauda) is described. An enzymic digestion followed by sedimentation of crude cell suspension on discontinuous Percoll gradient yielded quite pure active epithelial cell population as judged by morphological and functional studies. Electron microscopy analysis showed that cells from bands corresponding to densities 1.055 and $1.06 \mathrm{~g} / \mathrm{ml}$ of the gradient preserved a morphology compatible with their epithelial origin and their absorptive and secretory functions. Moreover, they stained positively with anticytokeratin antibody (95-97\%) and were negative for antidesmin antibody. They selectively bound L-carnitine through a timedependent and saturable system and differences in the rate of binding were apparent according to the three anatomical regions of the epididymis.
\end{abstract}

Keywords: epididymis; epithelial cells; cell purification; carnitine uptake; rat

\section{Introduction}

The fluid of the epididymal duct of mammals provides an appropriate environment for posttesticular maturation of spermatozoa. An abundance of data indicates that products concentrated from blood into the lumen and proteins secreted by the epididymal epithelium together with testicular factors contribute to the progressive motility and fertilizing capacity of spermatozoa (Moore, 1981; Orgebin Crist et al., 1981; Cuaniscu et al., 1984; Moore et al., 1986). These acquisitions progress as the male gamete crosses the diverse anatomical regions of the epididymis, the caput, corpus and cauda. The epididymis plays a crucial role in male fertility and defects in its function are responsible for several cases of human infertility (Menchini-Fabris et al., 1984; Blaquier et al., 1987). Therefore it appears to be a preferential target for antifertility programmes.

Cell purification followed by in-vitro culture is an invaluable method for analysing complex mechanisms specific for a precise cell type. Dissociation of the epididymis results in a crude suspension of spermatozoa, epithelial and smooth muscle cells, fibroblasts and leucocytes (Hamilton, 1975). Principal cells, the predominant cell type in the epithelium, are polarized and possess an apical network of microvilli. They are thought to be responsible for most of the absorption and secretion activities which are under the control of androgens. Many approaches have established protocols which yield only enriched cell suspensions after selective enzymic digestion (Kierszenbaum et al., 1981; Olson et al., 1982; Byers et al., 1985a, b). The best results were obtained with an elutriation procedure which requires expensive materials and tedious protocol (Klinefelter et al., 1982; Wagley et al., 1984).

In this communication we describe a simple and efficient method for purification of epididymal epithelial cells. The procedure involves the separation of epididymal cells by enzymic digestion followed by sedimentation of crude cell suspension on a discontinuous Percoll gradient. The preservation of morphological cell integrity was assessed by scanning electron microscopy studies and the 
purity of epithelial cell population was evaluated by immunochemical determination of cytoskeletal components. Retention of ability to take up carnitine by a specific mediator process was used as a monitor of cell viability and activity.

\section{Materials and Methods}

Purification of epithelial cells. Epididymides of adult Wistar rats ( 90 days old) were dissected free of fat and connective tissue, separated into caput, corpus and cauda and minced into small fragments under sterile conditions. Fragments were washed three times with RPMI 1640 medium to remove spermatozoa and incubated with trypsin $(0.5 \mathrm{mg} / \mathrm{ml})$, EDTA $(0 \cdot 2 \mathrm{mg} / \mathrm{ml})\left(\mathrm{GIBCO} / \mathrm{BRL}\right.$, Cergy-Pontoise, France) at $36^{\circ} \mathrm{C}$ for $20 \mathrm{~min}$ with gentle shaking. The samples were centrifuged at low speed $(200 \mathrm{~g}, 5 \mathrm{~min})$ and washed three times in Medium RPMI 1640 . The pellets were incubated in collagenase $(2 \mathrm{mg} / \mathrm{ml})$ in Medium RPMI for $2 \mathrm{~h}$ at $36^{\circ} \mathrm{C}$ with gentle shaking. The crude cell suspension was washed with medium three times and collected by centrifugation. About $100-120 \times 10^{6}$ cells, corresponding to two epididymides, were resuspended in $200 \mu$ l Medium RPMI and layered on top of each discontinuous Percoll gradient.

The Percoll gradients were prepared as described previously (Lefèvre et al., 1983). Twelve solutions containing increasing Percoll concentrations were obtained by mixing two stock solutions A and B prepared as follows. Solution A contained 9 parts of Percoll, 1 part of $10 \times$ Medium RPMI 1640, 20 mM-Hepes and $2.9 \%$ fetal calf serum (FCS). Solution B contained Medium RPMI 1640, $20 \mathrm{mM}$-Hepes, and 2.9\% FCS. Twelve solutions were prepared by mixing 20 to $80 \%$ Solution A with Solution B. For each solution, $2 \mathrm{ml}$ were layered carefully in $20 \mathrm{ml}$ sterile plastic tubes from the most dense to the least dense one at the top, providing a density gradient from $1 \mathrm{lo} 1.2 \mathrm{~g} / \mathrm{ml}$. After centrifugation for $20 \mathrm{~min}$ at $1100 \mathrm{~g}$ and $18^{\circ} \mathrm{C}$, cells were distributed in 9 bands corresponding to the interfaces between different Percoll concentrations. Each cell fraction was taken separately by pipetting, and washed twice with Medium RPMI 1640. Viability of cells was established by Trypan blue dye exclusion. Fractions 4-8 were then examined for their morphology determined by light and electron microscopy and immunohistochemistry and for their ability to bind carnitine. For culture, cells were plated in Medium RPMI 1640 containing 10\% FCS and testosterone (5 $\mu \mathrm{g} / \mathrm{ml})$. After $24 \mathrm{~h}$, the medium was replaced by Medium C (Medium RPMI 1640 containing $2 \% \mathrm{FCS}$, insulin $(5 \mu \mathrm{g} / \mathrm{ml}$ ), transferrin $(5 \mu \mathrm{g} / \mathrm{ml})$, vitamin E $(0 \cdot 2 \mu \mathrm{g} / \mathrm{ml})$, retinoic acid $(10 \mu \mathrm{g} / \mathrm{ml})$ and testosterone $(5 \mu \mathrm{g} / \mathrm{ml}))$ (Lefevre et al., 1985).

Phase-contrast microscopy. Crude and cultured cells were examined after either gradient sedimentation or $24 \mathrm{~h}$ to 5 days of culture.

Electron microscopy. Cell pellets from the different fractions were rinsed twice in Medium RPMI and fixed for $60 \mathrm{~min}$ at $4^{\circ} \mathrm{C}$ in Sörensen buffer containing $2 \%$ glutaraldehyde. Pellets were rinsed with Sörensen buffer and stained en bloc in agar and post-fixed in osmic acid $1 \%$ for $1 \mathrm{~h}$ at $20^{\circ} \mathrm{C}$. They were then rinsed, dehydrated through an ethanol series and embedded in Araldite. Thin sections were stained with uranyl acetate and lead citrate and photographed in Elmiskop CT 150 Siemens microscope.

Immunohistochemistry. Cells on glass coverslides at Day 5 of culture were rinsed twice with Medium RPMI 1640, fixed for $5 \mathrm{~min}$ in methanol at $-20^{\circ} \mathrm{C}$ and rinsed three times for $5 \mathrm{~min}$ each with cold PBS. Cells were incubated for $1 \mathrm{~h}$ with anticytokeratin 8 antibody which reacts with cytokeratin 8 and is specific for simple epithelia (Amersham, Bucks, UK) or antidesmin antibody (Biosys, Apeldoorn, Netherlands) diluted $1 / 5$ and $1 / 10$ respectively in PBS containing $0.5 \%$ bovine serum albumin in a dark box. They were then rinsed three times for $5 \mathrm{~min}$ each with PBS and incubated for $30 \mathrm{~min}$ with secondary antibody which was a goat antibody to mouse IgG FITC (Biosys) diluted 1/100 in PBS containing 0.5\% BSA and Evans blue. The coverslides were rinsed twice with PBS-BSA and mounted on glass slides with Fluoprep (Biomérieux, Lyon, France). Controls were incubated with human serum or with only the secondary antibody.

Binding of $\left.I^{3} \mathrm{H}\right]$ carnitine. Aliquots of each cell fraction (about $3 \times 10^{6}$ cells) were incubated for 0 to $120 \mathrm{~min}$ in $200 \mu l$ Medium C supplemented with $10 \mu \mathrm{Ci} \mathrm{L}-\left[{ }^{3} \mathrm{H}\right]$ carnitine $/ \mathrm{ml}$ (Amersham; sp. act. $70 \mathrm{Ci} / \mathrm{mmol}$ ) and $50 \mu \mathrm{mol}$ carnitine. Cells were rinsed three times with cold PBS containing $0.2 \%$ BSA. After the last centrifugation, pellets were solubilized in $100 \mu 10.5 \mathrm{~N}-\mathrm{NaOH}, 0.4 \%$ deoxycholate and bound radioactivity was measured. For saturation experiments, cells were incubated for $90 \mathrm{~min}$ at $35^{\circ} \mathrm{C}$ in Medium $\mathrm{C}$ containing increasing concentrations of L-carnitine (6.25-100 $\mu \mathrm{mol})$ with a constant amount of $\mathrm{L}-\left[{ }^{3} \mathrm{H}\right]$ carnitine $(10 \mu \mathrm{Ci} / \mathrm{ml})$. Non-specific binding was estimated in the presence of $25 \mathrm{mmol}$ unlabelled carnitine. As cells remained clustered even after enzymic digestion, results were expressed as $\mu \mathrm{mol}$ bound per $\mathrm{mg}$ protein. Protein concentrations were determined by the method of Lowry et al. (1951). All results were expressed as the mean \pm s.e. of several experiments as indicated in the figure legends.

Clone ID cells are derived from the LM mouse cell line and are considered as non-differentiated cells (Kit et al., 1963). They were propagated in Medium RPMI 1640 supplemented with $10 \%$ FCS.

\section{Results}

\section{Cell purification}

After centrifugation, cells were resolved into 9 bands located at the interfaces between different Percoll concentrations, each corresponding to a defined density. As judged by Trypan blue dye 
exclusion the first three bands contained damaged cells. Living cells ( $<5 \%$ cells coloured by Trypan blue) sedimented in bands $4-9$, corresponding to densities of 1.045, 1.05, 1.055, 1.06, 1.07 and $1.75 \mathrm{~g} / \mathrm{ml}$ respectively.

\section{Phase-contrast microscopy}

After 5 days in culture, cells originating from Bands 6 and 7 exhibited the cuboidal shape typical of epithelial tissues, whatever their origin (caput, corpus or cauda epididymidis). They were nearly confluent and an elevated rate of mitosis (about $12 \%$ ) was observed.

\section{Electron microscopy}

Cells in Bands 1-3 were damaged. Cells from Band 4 exhibited nuclei whose condensed heterochromatin was associated with the nuclear envelope. Their pale-staining cytoplasm contained numerous membrane-bound bodies, mitochondria and vesicles and little rough reticulum. This description corresponds to Halo cells which have been shown to share many features in common with lymphocytes or monocytes (Fig. 1a).

Cells from Bands 6 and 7 contained essentially polarized cells whose apical region showed characteristic, well developed microvilli, small invaginations or pits, mitochondria and many coated or uncoated vesicles (Fig. 1b). An elaborate Golgi apparatus formed of many saccules and vesicles occupied the supranuclear region with multivesicular bodies. The basal region was characterized by a highly irregular nucleus surrounded by an abundant rough endoplasmic reticulum, lipid droplets and dense granules. Cells often remained clustered and exhibited many functional contacts such as desmosomes. All these features are characteristic of epithelial cells. Some of them were associated with basal cells which exhibited a large nucleus enclosed by a small amount of cytoplasm and some clear and narrow cells were observed in clusters of principal cells from the caput fraction.

Band 5 corresponded to Halo cells mixed with epithelial cells. Bands 8 and 9 showed essentially isolated myoblasts.

\section{Immunohistochemistry}

Anticytokeratin 8 and antidesmin antibodies were tested on crude epididymis sections and were shown to bind specifically to epithelial cells (Fig. 2a) and myoblasts respectively (not shown). After 5 days in culture the majority of the cells originating from Bands 6 and 7 displayed specific staining with anticytokeratin 8 antibody and were therefore classified as epithelial cells (Fig. 2b).

Staining of each cell fraction at Day 5 after plating is shown in Fig. 3. Cells from Band 4 bound both antibodies very weakly: $15 \%$ of them were positive for cytokeratin and $10 \%$ for desmin. More cells stained positively with antidesmin antibody in Band 5. Cells from Bands 6 and 7 exhibited positive fibrillar staining with the cytokeratin 8 antiserum $(>95 \%)$ while less than $5 \%$ of the cells retained positive staining with antidesmin antibody. In Bands 8 and $9,80 \%$ of the cells were stained with antidesmin antibody and about $20 \%$ contaminating cells bound anticytokeratin antibody.

\section{Binding of $\left[{ }^{3} \mathbf{H}\right]$ carnitine}

Suspensions of purified cells from the caput, corpus and cauda epididymidis were compared for their ability to take up L-carnitine. Incubation of epithelial cells from the three anatomical regions at $35^{\circ} \mathrm{C}$ with $\left[{ }^{3} \mathrm{H}\right.$ ]carnitine and 500 -fold excess of unlabelled carnitine never exceeded $20 \%$ of total binding (data not shown). This non-specific uptake was deduced from the total to obtain the specific uptake.

Figure 4(a) shows that, after $60 \mathrm{~min}$, cells from the cauda epididymidis were able to take up $48.51 \pm 3.8 \mu \mathrm{mol}$ carnitine $/ \mathrm{mg}$ protein while cells from the caput epididymidis bound only 


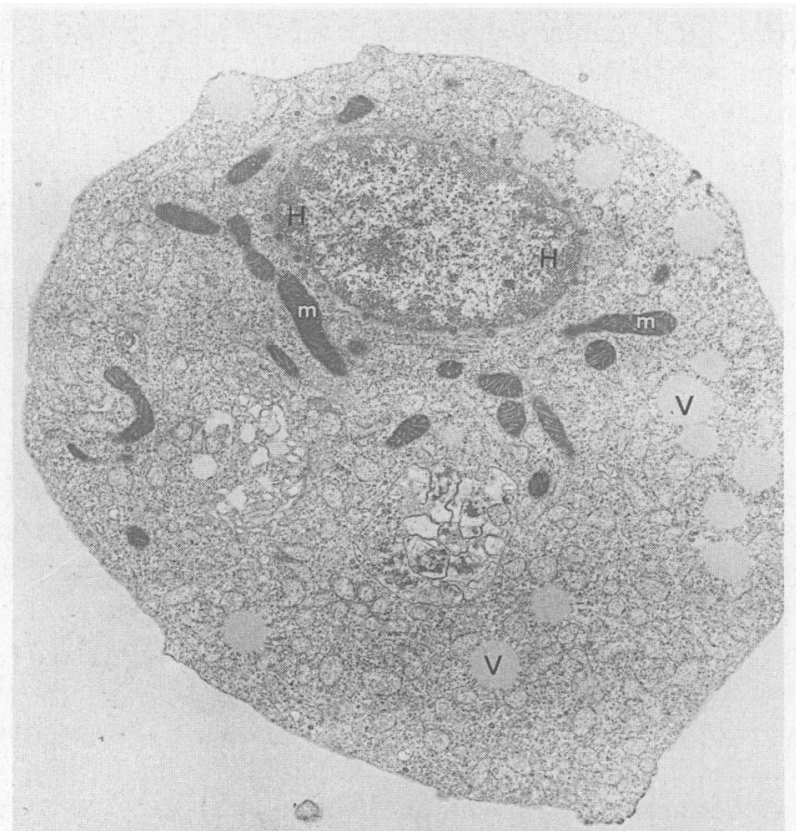

(a)

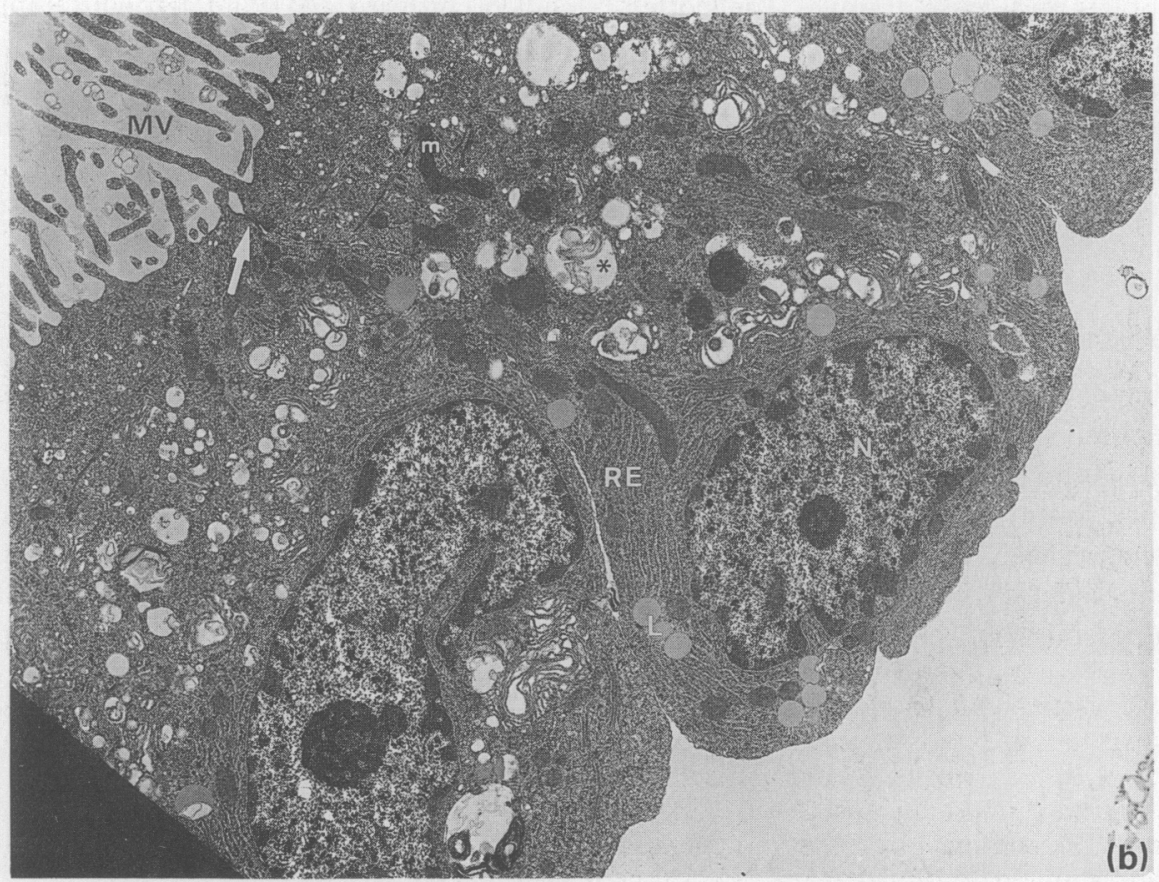

Fig. 1. Transmission electron micrographs of cells from the cauda epididymidis. (a) Halo cell from Band 4 of the Percoll gradient. It is characterized by heterochromatin associated with the nuclear envelope $(\mathrm{H})$, numerous mitochondria $(\mathrm{m})$ and pale vesicles $(\mathrm{V}) . \times 8000$. (b) Epithelial cells from Bands 6 and 7 of the Percoll gradient. The apex of the cells shows abundant microvilli (MV). Adjacent cells remain attached to each other by many desmosomes $(\rightarrow)$. $\mathrm{L}=$ lysosomes, $\mathrm{m}=$ mitochondria, $\mathrm{N}=$ nucleus, ${ }^{*}=$ multivesicular bodies, $\mathrm{RE}=$ endoplasmic reticulum. $\times 5000$. 

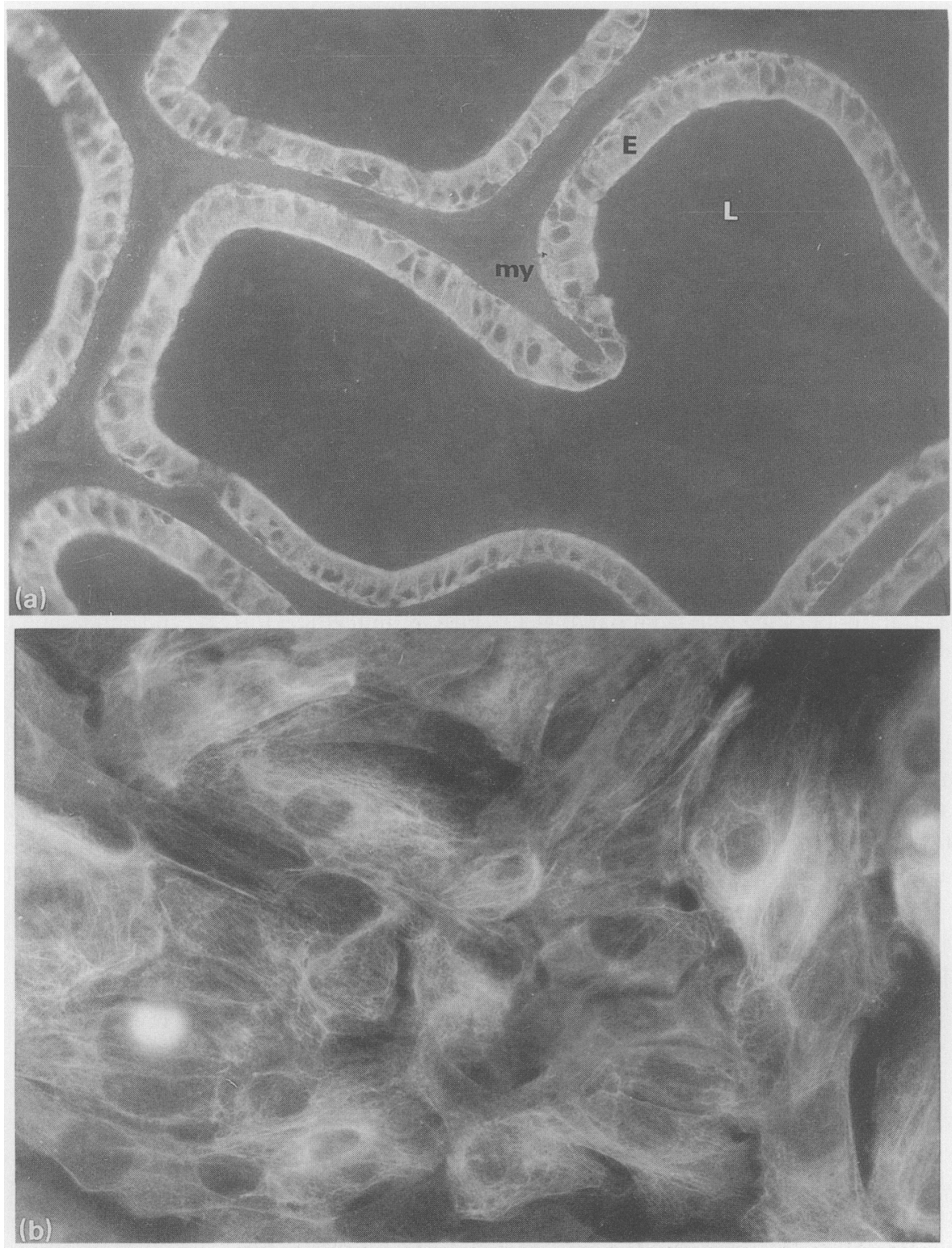

Fig. 2. Determination of keratin-containing intermediate filaments. (a) Fluorescence photomicrograph of a cryostat section of the cauda rat epididymidis incubated with anticytokeratin antibody. The lumen (L) and myoblasts (my) do not stain. $E=$ epithelium. $\times 200$. (b) Fluorescence photomicrograph of cauda cells from Bands 6 and 7 after 4 days of primary culture. Fluorescence results from incubation with anticytokeratin antibody. All the cells display staining of fibrillar elements in the cytoplasm. $\times 400$.

$22 \cdot 24 \pm 2 \mu \mathrm{mol}$ and corpus cells reached an intermediate value. Binding of carnitine by epithelial cells from the cauda epididymidis (Bands 6 and 7) was enhanced four times by comparison with cells from Band 4: $65.25 \pm 8$ and $16.40 \pm 1.75 \mu \mathrm{mol} / \mathrm{mg}$ protein, respectively (Fig. $4 \mathrm{~b}$ ). This residual activity in Halo cells was probably expressed by contaminating epithelial cells in Band 4 . The comparison between kinetics of carnitine uptake by cauda epithelial cells from Bands 6-7 and 


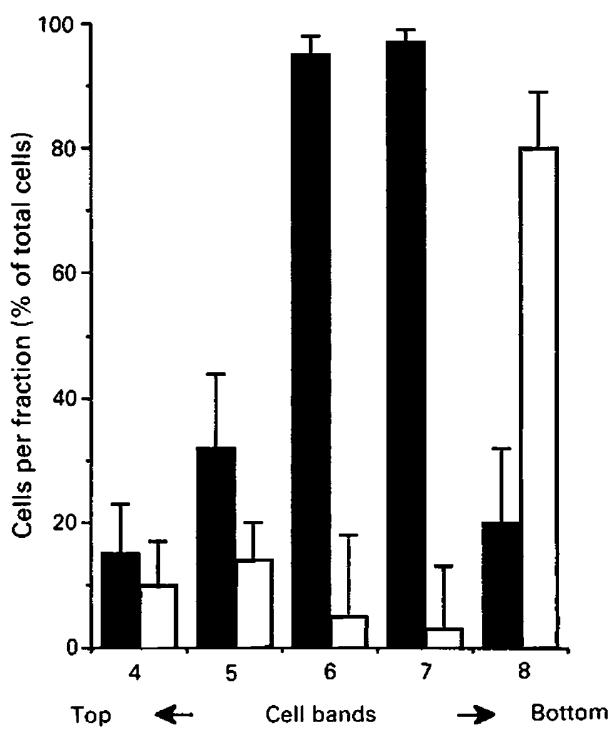

Fig. 3. Rates of cauda cells from Bands 4-8 stained by anticytokeratin ( $\square$ ) and antidesmin ( $\square$ ) antibodies after 4 days of culture.

that of clone 1D cells exhibited a time-dependent binding of carnitine for the former (Fig. 4c). The amount of carnitine bound by the epithelial cells reached a plateau at $60 \min (58.40 \pm 5 \mu \mathrm{mol} / \mathrm{mg}$ protein) while clone 1D cells continued to enhance binding within $120 \mathrm{~min}$. The saturation experiment showed that binding was saturable at $9.5 \mu \mathrm{mol} / \mathrm{mg}$ protein for epithelial cells while it was linear for clone 1D cells from 0 to $100 \mu \mathrm{mol}$ (data not shown).

As can be seen in Fig. 4(d), the binding of L-carnitine by epididymal cauda cells from Bands 6 and 7 took place through a time-dependent and saturable system with a $V_{\max }$ of $250 \mathrm{nmol}$ absorbed $/ \mathrm{min} / \mathrm{mg}$ protein and a $K_{\mathrm{m}}$ of $12 \mu \mathrm{mol}$. In contrast, binding by clone 1D cells was independent of time and was not a saturable phenomenon.

\section{Discussion}

To study functional characteristics of epididymal epithelium without confusion with other tissues, several attempts have been made to isolate populations of epithelial cells using different enzyme digestion procedures or the more efficient method of elutriation (Kierszenbaum et al., 1981; Olson et al., 1982; Klinefelter et al., 1982; Wagley et al., 1984; Byers et al., 1985a, b). Purity of cultures was assessed essentially by immunostaining of cytoskeletal components and electron microscopic analysis. In most cases enzymic digestion and elutriation led to enriched cell suspensions containing $70-85 \%$ epithelial cells and it was difficult to prevent the secondary proliferation of contaminating cells after plating. In the present study a purification on a discontinuous Percoll gradient was devised. The crude cell suspension was resolved into 9 sharp bands that are easy to collect.

Ultramicroscopical studies of isolated cells revealed that epithelial cells which sedimented in bands corresponding to densities 1.055 and $1.06 \mathrm{~g} / \mathrm{ml}$ displayed morphology suggestive of continued secretory and absorptive functions. They did not reveal any damage caused by enzyme treatment or the purification procedure, proving the innocuousness of Percoll. Cells were still associated by desmosomes and gap junctions but appeared free of fibroblasts, smooth muscle and Halo cells at their basal pole. They exhibited developed microvilli at the apical border, extensive rough endoplasmic reticulum, numerous Golgi vesicles, multivesicular bodies and vacuoles. The morphological preservation was correlated with cell viability as determined by further plating and 

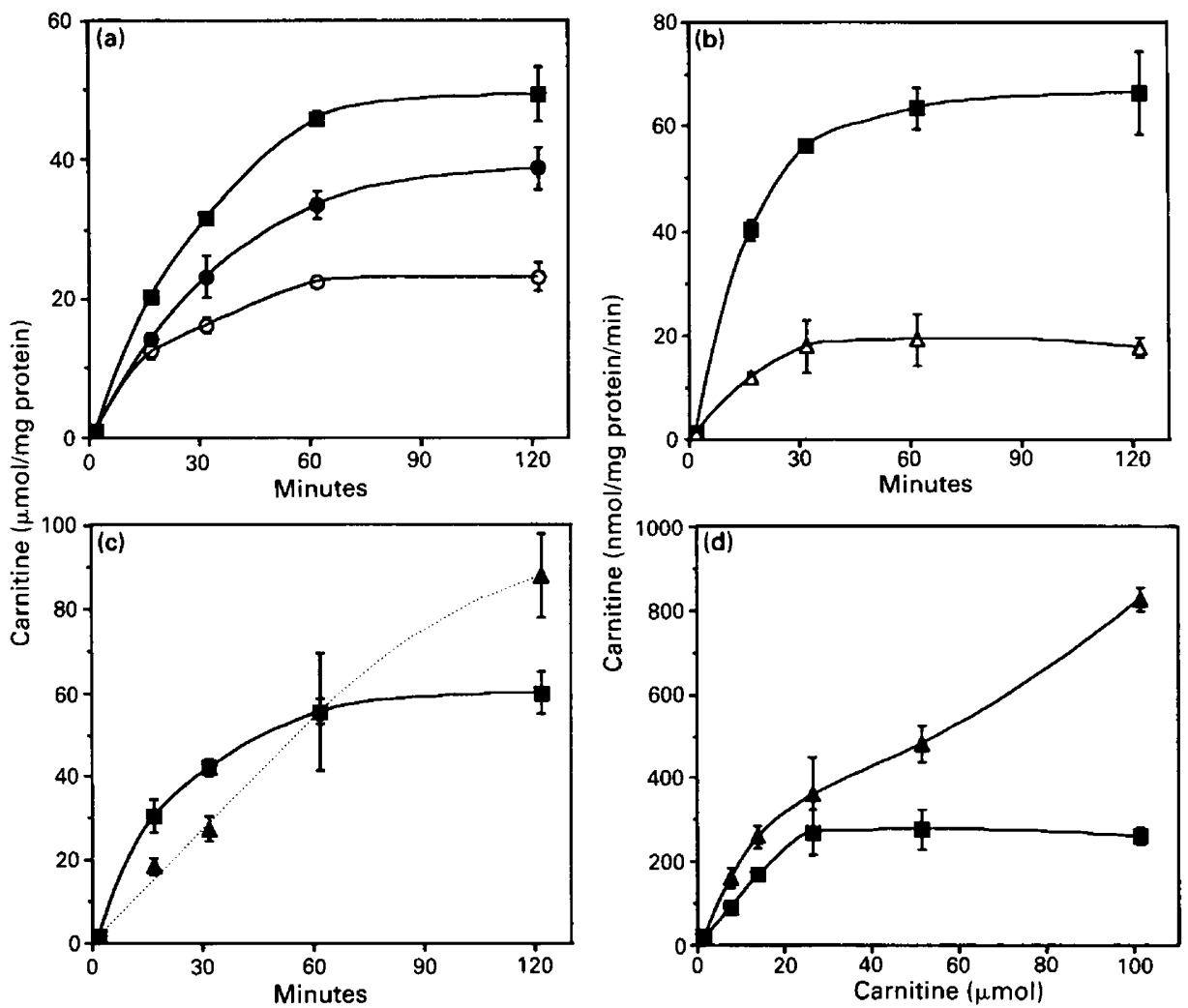

Fig. 4. Binding of carnitine. (a) Kinetics of carnitine binding by cells from Bands 6 and 7 from the caput $(O)$, corpus $(O)$ and cauda $(\boldsymbol{\square})$. (b) Kinetics of carnitine binding by cauda cells from Band $4(\triangle)$ and from Bands 6 and $7(\square)$. According to their morphological features they are regarded as Halo and epithelial cells respectively. (c) Kinetics of carnitine binding by cauda epithelial cells from Bands 6 and $7(\boldsymbol{Q})$ and clone 1D cells $(\boldsymbol{\Delta})$. (d) Saturation curves of carnitine binding by cauda epithelial cells from Bands 6 and $7(\boldsymbol{D})$ and clone 1D cells $(\boldsymbol{\Delta})$. (a) Results are means \pm s.d. of 3 independent experiments. (b, c, d) values are means \pm s.d. of triplicate determinations from 2 separate experiments.

multiplication of the cells. Halo cells and myoblasts sedimented in bands of densities 1.045 and $1 \cdot 07-1 \cdot 075 \mathrm{~g} / \mathrm{ml}$ respectively.

To monitor the relative degree of contamination of cell suspensions from each band, we used immunochemical determinations of cytoskeletal components 5 days after plating. The presence of keratin-containing intermediate filaments has been shown to be restricted to cells of epithelial origin and the presence of desmin to muscle cells (Franke et al., 1978). These criteria permit distinction between the two major cell types in the epididymis. Cells from Bands 6 and 7 formed a homogeneous monolayer and appeared polyhedral in shape and free of muscle cells as judged by weak antidesmin staining; $95-97 \%$ of cells exhibited deposition of filamentous keratin and in most preparations non-epithelial cell contamination was insignificant.

Several biochemical probes have been used to allow the identification of epithelial cells and to ascertain the maintenance of specific functions such as testosterone metabolism (Klinefelter $e t$ al., 1982), lectin binding and glucuronidase activity (Franke et al., 1978; Olson et al., 1982), androgenbinding protein captation (Skudlarek \& Orgebin-Crist, 1986), protein synthesis and release (Kierszenbaum et al., 1981; Klinefelter et al., 1982; White et al., 1982; Skudlarek \& Orgebin-Crist, 1986) and development of a permeability barrier (Olson et al., 1983). However, these functions are 
not expressed uniformly and some are confined to very defined anatomical segments. In contrast, the accumulation of carnitine from blood to intraluminal fluid, which has been shown to be expressed at high rates by the three anatomical regions of the rat epididymis, appears to be a good discriminating probe: carnitine concentration in the cauda may be up to 1600 times greater than in blood (Hinton et al., 1979) and the concentration of carnitine in the intraluminar fluid has been correlated with the development of sperm motility.

We compared the uptake of carnitine by purified epithelial cells from the caput, corpus and cauda epididymidis and showed that cauda cells are two times more efficient at binding carnitine than are caput cells. These results are supported by the findings of Hinton et al. (1979) and Jeulin et al. (1987) who detected increases in carnitine amounts in cauda epididymal fluid of different species. However, data from micropuncture and perfusion techniques identified the caput and corpus epididymidis as more active regions than the cauda epididymidis in the transport of Lcarnitine from the circulation to the epididymal lumen (Hinton \& Setchell, 1979; Yeung et al., 1980; Hinton, 1985). These discrepancies probably result from the inability to restore in vitro the luminal environment specific for each epididymal region, since a number of factors influence the transport of carnitine (Yeung et al., 1980). Furthermore, carnitine has access to all surfaces of isolated cells in vitro whereas it only reaches their basal pole in vivo. Our results from analysis of cell suspensions are the result of three phenomena: the uptake of carnitine at the basal pole of cells, its efflux from the cell apex, and the reabsorption of intraluminar carnitine by the apical pole (Hinton $\&$ Hernandez, 1985).

Binding of carnitine was prevented by incubation of the cells with excess unbound carnitine, indicating that this uptake was by a specific receptor mediator process. In contrast, carnitine binding by the undifferentiated cell line clone $1 \mathrm{D}$ has been determined to be a non-specific event. Therefore the uptake of carnitine appears as a good probe of epithelial cell functional state and should allow the identification of epithelial cells from any region of epididymis.

The procedure described here allows the purification of epithelial cells and elimination of any contaminating cell types present in the epididymis. We are currently using this system to establish purified cells in culture which continue to express the functions they display in vivo. This technique should be useful for the comprehension of regulation mechanisms of sperm maturation and may provide insights into epithelial contribution to sperm-oocyte recognition and fertilization.

We thank M. Couvillers for electron microscopy analysis, S. Magre for stimulating discussion; and L. Schupack for critical reading of the manuscript.

\section{References}

Blaquier, J.A., Cameo, M.S., Stephany, D., Piazza, A., Tezon, J.G. \& Shering, R.T. (1987) Abnormal distribution of epididymal antigens on spermatozoa from infertile men. Fert. Steril. 47, 302-309.

Byers, S.W., Hadley, M.A., Djakiew, D. \& Dym, M. (1985a) Growth and characterisation of polarized monolayers of epididymal epithelial cells and Sertoli cells in dual environment culture chambers. $J$. Androl. 7, 59-68.

Byers, S.W., Djakiew, D. \& Dym, S. (1985b) Structural features of rat epididymal epithelial cells in vitro. $J$. Reprod. Fert. 75, 401-411.

Cuaniscu, P.C., Gonzalez Echeverria, F., Piazza, A., Pineiro, L. \& Blaquier, J. (1984) Epididymal proteins mimic the androgenic effect on zona pellucida recognition by immature hamster spermatozoa. J. Reprod. Fert. 71, 427-431.

Franke, W.W., Schmid, E., Osborn, M. \& Weber, K. (1978) Different intermediate sized filaments dis- tinguished by immunofluorescence microscopy. Proc. natn. Acad. Sci. USA 75, 5034-5038.

Hamilton, D.W. (1975) Structure and functions of epithelium lining the ductuli efferentes, ductus epididymidis and ductus deferens in the rat. In Handbook of Physiology, pp. 259-300. Eds R. O. Greep \& E. B. Astwood. American Physiology Society, Washington, DC.

Hinton, B.T. (1985) The blood epididymis barrier. In Male Fertility and its Regulation, pp. 371-390. Eds T. J. Lobl \& E. S. E. Hafez. M.I.P. Press, Lancaster.

Hinton, B.T. \& Hernandez, H. (1985) Selective luminal absorption of L carnitine from the proximal regions of the rat epididymis. J. Androl. 6, 300-305.

Hinton, B.T. \& Setchell, B.P. (1979) Concentration and uptake of carnitine in the rat epididymis. A micropuncture study. In Carnitine Biosynthesis, pp. 237-250. Eds J. D. MacGarry \& R. A. Frankels. Academic Press, New York. 
Hinton, B.T., Snoswell, A.M. \& Setchell, B.P. (1979) Concentration of carnitine in the luminal fluid of the testis and epididymis of the rat and some other mammals. J. Reprod. Fert. 56, 105-111.

Jeulin, C., Soufir, J.C., Marson, J., Paquignon, M. \& Dacheux, J.L. (1987) The distribution of carnitine and acetylcarnitine in the epididymis of the boar. $J$. Reprod. Fert. 79, 523-529.

Kierszenbaum, A.L., Lea, O., Petrusz, P., French, F.S. \& Tres, L.T. (1981) Isolation, culture and immunocytochemical characterisation of epididymal epithelial cells from pubertal and adult rats. Proc. natn. Acad. Sci. USA 78, 1675-1679.

Kit, S., Dubbs, D. R., Piekarski, L.I. \& Hsu, T.C. (1963) Deletion of thymidine kinase activity from $\mathrm{L}$ cells resistant to bromodeoxyuridine. Expl Cell Res. 31, 297-301.

Klinefelter, G.R., Amann, R.P. \& Hammersteadt, R.H. (1982) Culture of principal cells from the rat caput epididymis. Biol. Reprod. 26, 885-901.

Lefèvre, A., Saez, J.M. \& Finaz, C. (1983) hCG responsiveness of purified Leydig cells from immature and mature rats. Hormone Res. 17, 114-120.

Lefèvre, A., Finaz, C., Berthelon, M.C. \& Saez, J.M. (1985) Modulation of cultured mouse Leydig cells adenylate cyclase by Forskolin and hCG. Molec. cell. Endocrinol. 40, 107-114.

Lowry, O.H., Rosebrough, N.J., Farr, A.L. \& Randall, R.J. (1951) Protein measurement with the folin phenol reagent. J. biol. Chem. 193, 265-275.

Menchini-Fabris, G.F., Canale, D., Izzo, P.L., Olivieri, L. \& Bartelloni, M. (1984) Free L carnitine in human semen: its variability in different andrologic pathologies. Fert. Steril. 42, 263-267.

Moore,H.D.M. (1981) Glycoprotein secretion of the epididymis in the rabbit and hamster: localisation on epididymal spermatozoa and effect of specific antibodies on fertilization in vivo. J. exp. Zool. 215, 77-85.
Moore, H.D.M., Hartman, T.D. \& Smith, C.A. (1986) Invitro development of the fertilizing ability of hamster epididymal spermatozoa after coculture with epithelium from proximal cauda epididymidis. $J$. Reprod. Fert. 78, 327-336.

Olson, G.E., Jonas-Davies, J., Hofiman, L.H. \& Orgebin Crist, M.C. (1982) Structural characterisation of isolated rat epididymal epithelial cells. Gamete Res. 6, $161-178$.

Olson, G.E., Jonas-Davies, J., Hoffman, L.H. \& Orgebin Crist, M.C. (1983) Structural features of cultured epithelial cells from the adult rat epididymis. $J$. Androl. 4, 347-360.

Orgebin Crist, M.C., Olson, G.E. \& Danzo, B.I. (1981) Factors influencing maturation of spermatozoa in the epididymis. In Intragonadal Regulation of Reproduction, pp. 393-418. Eds P. Franchimont \& C. P. Channing. Academic Press, London.

Skudlarek, M.J. \& Orgebin-Crist, M.C. (1986) Glucosidases in cultured rat epididymal cells: enzyme activity, synthesis and secretion. Biol. Reprod. 35, 167-178.

Wagley, L.M., Verluis, T.D., Brown, D.V. \& Amann, R.P. (1984) Culture of principal cells from the ram epididymis. J. Androl. 5, 389-408.

White, M.G., Huang, Y.S., Tres, L.T. \& Kierszenbaum, A.L. (1982) Structural and functional aspects of cultured epididymal epithelial cells isolated from pubertal rats. J. Reprod. Fert. 66, 475-484.

Yeung, C.H., Cooper, T.G. \& Waites, G.M.H. (1980) Carnitine transport into the perfused epididymis of the rat: regional differences, stereospecificity, stimulation by choline, and the effects of other luminal factors. Biol. Reprod. 23, 294-304.

Received 9 July 1990 